\title{
Marine Fish Marketing Problems at Satpati Landing Center in Palghar District
}

\author{
Girish Jadhav ${ }^{1}$ and Sachin Borgave ${ }^{2}$ \\ ${ }^{1}$ Ph.D. Scholar, Savitribai Phule Pune University \& Assistant Professor \\ of Marketing, MMS Department, Navinchandra Mehta Institute of Technology \\ and Development, Dadar (West), Maharashtra, India \\ ${ }^{2}$ Director, Pratibha Institute of Business Management \&t Ph. D. Guide, Savitribai \\ Phule Pune University, Pune, Maharashtra, India
}

\section{ABSTRACT}

Fishing assumes a significant part in supporting livelihoods worldwide and furthermore frames a significant source of diet for more than one billion individuals. Fisheries area assumes a significant part in the Indian economy via adding to the income of nation, jobs, and foreign exchange. The principal goals of the study are to investigate the issues of fish promoting in Palghar Market. The current investigation has been founded on primary information gathered from the fishermen. The information has been gathered with the assistance of the questionnaires and survey and the respondents are chosen by convenience sampling. The sample size for the investigation is 75 fishermen. It is discovered that the significant issues of fish marketing of fishermen are storage, transportation, and quality. The issues of fish marketing could be tackled effectively with the assistance of co-operative societies and Government.

\section{KEY WORDS: FISHERMEN PROBLEMS, FISH MARKETING, FISH QUALITY, COLD STORAGE, TRANSPORTATION.}

\section{INTRODUCTION}

Marketing assumes a significant role in advancing the production of any commodity. The creation of food items like fish, vegetables, organic products, and so forth which are perishable in nature relies altogether upon a proficient marketing framework. In this angle, fisheries are521a assumes a significant part in the Indian economy via adding to the income of nation, jobs, and foreign exchange. Fish and fishery items are traded to more than 52 nations. More than 6000 crores of rupees of foreign exchange have been procured by the fisheries

Biosc Biotech Res Comm P-ISSN: 0974-6455 E-ISSN: 2321-4007

\section{crossef}

Identifiers and Pagination

Year: 2021 Vol: 14 No (5) Special Issue

Pages: 51-55

This is an open access article under Creative

Commons License Attribn 4.0 Intl (CC-BY). DOI: $h t t p: / / d x . d o i . o r g / 10.21786 / b b r c / 14.5 / 11$ area. Fish exchange acquires significance both at national and international levels. Consequently, it gives ways and means of living and income. Along these lines, fisheries are imperative to humanity in all nations, especially in non-industrial countries like India for it focuses on creation of fish food, gives available resources of living and earning, offers job openings and assumes a crucial part in improving the economy of by far most of individuals associated with fishing profession.

Statement of the problem: Fish being an exceptionally transitory product, its showcasing accepts unique importance. It needs good infrastructure like roads, transport facilities, appropriate storage, ice, Large Refrigerators to keep fish for longer time, and cooperative societies. Such facilities are not accessible to fishermen up to their need intensity and the fishermen faces more issues. So, it is an endeavored to examine the issues of fish marketing at Satpati landing center in Palghar district.

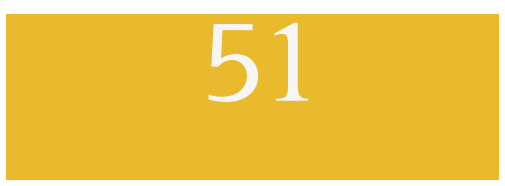


Objectives of the study: To explore the fish marketing problems at Satpati landing center in Palghar district, to offer suggestions based on the findings of the study.

\section{METHODOLOGY}

The research methodology portrays the steps for the study. It provides clear direction to the researcher to continue with the examination. It incorporates sampling method, sample size and collection of data. The current examination has been founded on essential information gathered from the fishermen. The information has been gathered with the assistance of the survey and the respondents are chosen by convenience sampling. The sample size for the investigation is 75 fishermen.

Table 1. Age Wise Distribution of Respondents

\begin{tabular}{|l|c|c|}
\hline Age & No. of Respondents & Percentage \\
\hline Below 30 & 08 & 11 \\
\hline $31-40$ & 31 & 41 \\
\hline $41-50$ & 15 & 20 \\
\hline Above 50 & 21 & 28 \\
\hline Total & 75 & 100 \\
\hline
\end{tabular}

Source: Primary data

Table 2. Marital Status Wise Distribution of Respondents

\begin{tabular}{|l|c|c|}
\hline Marital Status & No. of Respondents & Percentage \\
\hline Married & 64 & 85.3 \\
\hline Unmarried & 11 & 14.7 \\
\hline Total & 75 & 100 \\
\hline
\end{tabular}

Source: Primary data

Table 3. Family System Wise Distribution of Respondents

\begin{tabular}{|l|c|c|}
\hline Family System & No. of Respondents & Percentage \\
\hline Joint Family & 31 & 41 \\
\hline Nuclear Family & 44 & 59 \\
\hline Total & 75 & 100 \\
\hline \multicolumn{2}{|l}{ Source: Primary data } \\
\hline
\end{tabular}

Limitations of the study: No significant investigations have been led on the issues of the fish marketing and promotion; so there exists a wide information gap in this regard. This examination should be basically seen as a beginning stage in endeavoring to uncover the current realities of fishermen community in local area. Non-accessibility of adequate and reliable information is one of the significant constraints of the examination. In absence of appropriate records, the examination exclusively relies upon information given by the fishermen regarding their conditions.

Data Analysis and Interpretation: Table. 1 reveals that 41 per cent are in the age group of 31 to 40 and 28 per cent are in the age group of above 50 years, 20 per cent are in the age group of 41 to 50 years, and 11 per cent are in the age group of below 30 years. It denotes that most of the fishermen involved in fish marketing at satpati landing center in Palghar district are 31 to 40 years of age and the persons below 30 years of age are rarely involved in marketing of fish in the study area.

Table. 2 reveals that 85.3 per cent are married and 14.7 per cent are unmarried. It divulges that married individuals are highly involved in marketing of fish at satpati landing center in Palghar district.

Table. 3 reveals that 59 per cent belong to nuclear family and 41 per cent belong to joint family. Thus, it is concluded that most of the fishermen in the study area are living in nuclear families.

Table 4. Educational Qualification Wise Classification of Respondents

\begin{tabular}{|l|c|c|}
\hline $\begin{array}{l}\text { Educational } \\
\text { Qualification }\end{array}$ & $\begin{array}{c}\text { No. of } \\
\text { Respondents }\end{array}$ & Percentage \\
\hline Illiterate & 26 & 35 \\
\hline Up to 5th & 11 & 15 \\
\hline 5th to 8 & 14 & 19 \\
\hline SSLC-HSC & 20 & 26 \\
\hline Undergraduate & 04 & 5 \\
\hline Total & 75 & 100 \\
\hline Source: Primary data & \\
\hline
\end{tabular}

Table 5. Monthly Income Wise Distribution of Respondents

\begin{tabular}{|l|c|c|}
\hline $\begin{array}{l}\text { Monthly } \\
\text { Income }\end{array}$ & $\begin{array}{c}\text { No. of } \\
\text { Respondents }\end{array}$ & Percentage \\
\hline Below Rs.5000 & 22 & 29 \\
\hline Rs.5001 - Rs.10000 & 33 & 44 \\
\hline Rs.10001 - Rs.20000 & 17 & 23 \\
\hline Above Rs.20000 & 03 & 4 \\
\hline Total & 75 & 100 \\
\hline Source: Primary data & & \\
\hline
\end{tabular}

Table. 4 shows that 35 per cent are illiterates, 26 per cent are SSLC to HSC educational qualification, 19 per cent are 5th standard to 8th standard, 15 per cent are up to 5th standard and 5 per cent are undergraduates. It is evident from table that majority of the respondents are illiterate in the study area. 
Table. 5 clearly shows that 44 per cent earn a monthly income of Rs.5000 to Rs.10000, 29 per cent earn a monthly income of below Rs.5000, 23 per cent earn a monthly income of Rs. 10000 to Rs. 20000 and 4 per cent earn a monthly income of above Rs.20000. It is clear from table that majority of the respondents earn a monthly income of Rs.5000 to Rs. 10000.

Table. 6 reveals that 40 per cent have been involved in fishing for 5 to 10 years, 39 per cent have been involved in fishing for above 10 years, 14 per cent have been involved in fishing for 1 to 5 years and 7 have been involved in fishing for below 1 year.

Table 6. Number of Years Involved in Fishing

\begin{tabular}{|l|c|c|}
\hline $\begin{array}{l}\text { Number of Years } \\
\text { Involved in Fishing }\end{array}$ & $\begin{array}{c}\text { No. of } \\
\text { Respondents }\end{array}$ & Percentage \\
\hline Below 1 Year & 05 & 7 \\
\hline 1 to 5 YEARS & 11 & 14 \\
\hline 5 to 10 years & 30 & 40 \\
\hline Above 10 Years & 29 & 39 \\
\hline Total & 75 & 100 \\
\hline
\end{tabular}

Source: Primary data

Table.7 reveals that 61 per cent belong to mechanized type of fishing and 39 per cent belong to non- mechanized type of fishing.

Table. 8 shows that majority of 64 per cent of the respondents are involved in fishing for about 200 days and above in a year. The fishing period in a year is found to be between 100 and 200 days for 24 per cent of the respondents while the remaining 12 per cent of the respondents have a fishing period of below 100 days. It reveals that most of the respondents could be engaged in fishing for a period of 200 days or more.
Table 7. Type of Fishing

\begin{tabular}{|l|c|c|}
\hline Type of Fishing & No. of Respondents & Percentage \\
\hline Mechanized & 46 & 61 \\
\hline Non-Mechanized & 29 & 39 \\
\hline Total & 75 & 100 \\
\hline \multicolumn{2}{|l}{ Source: Primary data } \\
\hline
\end{tabular}

Table 8. Fishing Period in a Year

\begin{tabular}{|l|c|c|}
\hline $\begin{array}{l}\text { Fishing } \\
\text { Period in a Year }\end{array}$ & $\begin{array}{c}\text { No. of } \\
\text { Respondents }\end{array}$ & Percentage \\
\hline Below 100 Days & 9 & 12 \\
\hline 100 - 200 Days & 18 & 24 \\
\hline Above 200 Days & 48 & 64 \\
\hline Total & 75 & 100 \\
\hline \multicolumn{2}{l|}{} \\
Source: Primary data \\
\hline
\end{tabular}

Table 9 clearly shows that 53.3 per cent of the fishermen faced storage problems, 53.3 per cent of the fishermen faced quality issues and 41.3 per cent of the fishermen faced the problem in transportation. Fishermen of different age groups have different problems of fish marketing. To find out the significant difference in problems of fish marketing among different age group of fishermen at Satpati landing center in Palghar district, 'ANOVA' test is attempted with the null hypothesis, "there is no significant difference in problems of fish marketing among different age group of fishermen at Satpati landing center in Palghar district". The result of 'ANOVA' test is presented in the Table 10.

\section{Table 9. Problems in Fish Marketing}

\begin{tabular}{|l|c|c|c|c|c|c|}
\hline Problems of Fish Marketing & SA & A & N & DA & SDA & Total \\
\hline Over exploitation by middleman & $25(33.3)$ & $29(38.7)$ & $4(5.3)$ & $9(12)$ & $8(10.7)$ & $75(100)$ \\
\hline Price fluctuations & $28(37.3)$ & $22(29.3)$ & $8(10.7)$ & $8(10.7)$ & $9(12)$ & $75(100)$ \\
\hline Inadequate demand & $29(38.7)$ & $18(24)$ & $7(9.3)$ & $13(17.3)$ & $8(10.7)$ & $75(100)$ \\
\hline Low price offered by the buyer & $24(32)$ & $27(36)$ & $5(6.7)$ & $8(10.7)$ & $11(14.7)$ & $75(100)$ \\
\hline Storage problems & $40(53.3)$ & $26(34.7)$ & $2(2.7)$ & $4(5.3)$ & $3(4)$ & $75(100)$ \\
\hline Quality issues & $22(29.3)$ & $40(53.3)$ & $4(5.3)$ & $5(6.7)$ & $4(5.3)$ & $75(100)$ \\
\hline Inadequate market knowledge & $30(40)$ & $28(37.3)$ & $5(6.7)$ & $6(8)$ & $6(8)$ & $75(100)$ \\
\hline Competition from other sellers & $31(41.3)$ & $24(32)$ & $8(10.7)$ & $5(6.7)$ & $7(9.3)$ & $75(100)$ \\
\hline Transportation problems & $29(38.7)$ & $31(41.3)$ & $4(5.3)$ & $6(8)$ & $5(6.7)$ & $75(100)$ \\
\hline Delay in payment & $23(30.7)$ & $28(37.3)$ & $6(8)$ & $9(12)$ & $9(12)$ & $75(100)$ \\
\hline
\end{tabular}

Source: Primary data

(SA-Strongly Agree, A-Agree, N-Neutral, DA-Disagree and SDA-Strongly Disagree) 
Table 10 shows the mean score of problems of fish marketing along with its respective ' $F$ ' statistics. The important problems of fish marketing among fishermen are storage problems and price fluctuations and their respective mean scores are 4.3684 and 4.3654 . Regarding the problems of fish marketing, the significant difference among the different age group of fishermen, are identified in the case of price fluctuations and low price offered by the buyer since the respective ' $\mathrm{F}$ ' statistics are significant at 5 per cent level, the null hypothesis is rejected.

Table 10. Problems of Fish Marketing Among Different Age Group of Fishermen - ANOVA

\begin{tabular}{|l|c|c|c|c|c|c|}
\hline \multirow{2}{*}{ Problems of Fish Marketing } & \multicolumn{3}{c|}{$\begin{array}{c}\text { Age Group of Fishermen } \\
\text { (Mean Score) }\end{array}$} & F & p Value \\
\cline { 2 - 7 } & Below 30 & $31-40$ & $41-50$ & Above 50 & & \\
\hline Over Exploitation by middleman & 3.8333 & 4.0125 & 3.4848 & 3.8421 & 0.652 & 0.584 \\
\hline Price Fluctuations & 4.3654 & 3.6471 & 4.0909 & 2.7895 & 4.981 & 0.003 \\
\hline Inadequate Demand & 2.6657 & 3.8824 & 3.9394 & 3.1579 & 2.453 & 0.070 \\
\hline Low Price Offered by the Buyer & 1.6325 & 3.5294 & 4.2121 & 3.2105 & 8.106 & 0.000 \\
\hline Storage problems & 4.3212 & 4.2353 & 4.3124 & 4.3684 & 0.074 & 0.974 \\
\hline Quality Issues & 4.1245 & 3.8235 & 3.9697 & 3.9467 & 0.101 & 0.959 \\
\hline Inadequate Market Knowledge & 3.6542 & 4.2306 & 3.8485 & 3.8947 & 0.481 & 0.697 \\
\hline Competition from Other Sellers & 3.8933 & 4.1234 & 3.9091 & 3.6316 & 0.532 & 0.662 \\
\hline Transportation Problems & 3.3301 & 3.8474 & 3.9773 & 3.7895 & 1.383 & 0.255 \\
\hline Delay in Payment & 3.6267 & 3.3158 & 3.9412 & 3.3158 & 0.633 & 0.596 \\
\hline Source: Computed data & & & & & & \\
\hline
\end{tabular}

\section{Suggestions}

1. To decrease the problems of fish marketing, sufficient storage spaces must provide the fishermen. Due to perishability of fish the preservation facility like cold storage should provide.

2. To increase the satisfaction level, the consumer needs to purchase the fish at the landing center. The fish price ought to be fixed properly, reasonably and ought to be disbursed immediately. The consumer ought to purchase the various assortments of fish.

3. The secondary education and secondary income source should be provided to fishermen and their family members. The educational level could help the fishermen to identify the different selling points where the fish products could be sold, so that their market knowledge gets increased.

4. The government should support for cooperative societies and take steps for the export of fish. Hence, the fishermen could get more profit by exporting fish and fish products.

5. The Government should ensure that its official schemes will support the fishermen in financial ways also. The fishermen should be invited for meeting frequently so that they will get a chance to discuss various problems they have faced.

6. It is also suggested that the fishermen should be provided training for increasing their fishing ability and marketing skills. The fishermen are also to be provided with accident benefit schemes and insurance facility.

7. The infrastructure facility should be improved, and Government should take various steps to solve the problems faced by the fishermen in marketing their products.

\section{CONCLUSION}

Fish consumption is by all accounts increasing everywhere on the world. Fish and fish products are getting well known among the young consumers. The medicinal usage of fish products ought to be investigated to the consumers. The issues of fish marketing should be tackled by the Government and the co-operative society by expanding its nature of administrations and increasing its quality of services. It brings about the upgrade of level of fulfillment of fishermen towards the consumer. The role of co-operative fisheries society in the arrangement of different Gov. schemes and facilities administrations to the fishermen community is very important. The infrastructure facility like storage facility, transportation facility, and selling facility, etc. should be improved so that the quality of the fish and fish product can be maintained to highest level.

\section{REFERENCES}

Ayyappan, S., and Krishnan (2004) Fisheries sector in India: Dimensions of development. Indian Journal of Agricultural Economics, 59(3): 392-412. Nyaupane, P. $\mathrm{N}$ and J. M, Gillespie "Factors Influencing Producers'

Marketing Decisions in the Louisiana Crawfish Industry", Louisiana State, University Agricultural Centre, Bolton Rounge, LA, 2010.

Ayyappan S, and Krishnan, Fisheries sector in India: Dimensions of development, Indian Journal of Agricultural Economics, 59 (3), 2004, 392-412.

Bishnoi, Tanuj Kumar (2005) Marketing of Marine Fisheries, Sonali Publication, New Delhi, pp. 74-76. 
Bishnoi, Tanuj Kumar, Marketing of Marine Fisheries, Sonali Publication, New Delhi, 2005, 74-76. Ganesan, Marketing of marine fish - An empirical study in coastal villages in Palghar, Madurai, 1987.

Kumar, Ganesh B., K.K. Datta, P.K. Katiha, R. Suresh, T. Ravisankar, K. Ravindranath and Muktha Menon, (2008). Domestic Fish Marketing in India -Changing structure, conduct, performance, and policies. Agriculture Economics Research Review, Vol. 23 Jan.-June,: 345354.

Kumar, R. (2008). Domestic Marketing of Fish and fishery products in India - opportunities and challenges. In: National workshop on Development of strategies for Domestic Marketing of Fish and fishery products held at college of fisheries sciences, Nellore, India7-8 feb.:43-48.

Madugu, A. J. and Edward, A. (2011). Marketing and Distribution Channel of Processed Fish in Adamawa Narayanakumar, R. and Sathiadhas, R. 2006, Domestic fish marketing opportunities for marine fisheries sector in India. In: proceedings of the National workshop on post-harvest methods and domestic fish marketing opportunities, p. 59-67.

Ravindranath, K. (2008) In National Workshop on Development of Strategies for Domestic Marketing of Fish and Fishery Products, College of Fisheries Science, Nellore, India, pp. 43-48.

Sam Bennet P, and Arumugam, New Trends in the Traditional marine fisheries at Tuticorin, CMFRI Bulletin, Cochin, 44 (1), 1988, 155-158.

Sathiadhas R, and Panikkar K.K.P, Socio-economic status of marine fisheries along Madras coast, marine fisheries information service, Technical and extension service, Cochin, 90, 1989, 1-5.

Sathiadhas, R. and Narayanakumar, R. 1994. Price policy and fish marketing system in India, Biol. Educ., II (4): 225-241.

Srivastava, Uma Kant (1985) Inland Fish Marketing in India (Volume I - Overview: Summary and Conclusions), IIM Ahmedabad \& Concept Publishing Company, New Delhi.

State, Nigeria. Global Journal of Management and Business Research, volume 11, issue 4, version1.0, March 2010. 